\title{
"Judas mercator pessimus" de Pe. José Mauricio Nunes Garcia: o espaço da significação musical na expressão do motete
}

\author{
"Judas mercator pessimus" by Pe. José Maurício Nunes Garcia: the space \\ of musical significance in the expression of motet
}

\author{
Rodrigo Lopes da Silva \\ Diósnio Machado Neto \\ Universidade de São Paulo
}

\begin{abstract}
Resumo: Inserido na linha de pesquisa dedicada ao estudo da significação musical e, como parte de um projeto de pesquisa do curso de mestrado em musicologia da Escola de Comunicação e Artes da Universidade de São Paulo (USP), este artigo se propõe a iniciar uma investigação sobre a importância desse saber/prática na definição do próprio gênero, o motete. Isso porque, a essência deste gênero tem na palavra o seu núcleo. Como ponto de partida estudaremos o motete "Judas mercator pessimus" de Pe. José Maurício Nunes Garcia sob a perspectiva da retórica clássica, principalmente apoiado na teoria das tópicas. Assim, buscaremos compreender e demonstrar o comportamento das estruturas discursivas da música e como sua expressão, por meio da significação, vem a se relacionar com as proposições do texto. Por fim, buscaremos observar em que ponto as estruturas musicais encontram-se em ressonância com as estruturas de pensamentos (mentalidades e ideologias) e, no presente caso, quais seriam os embasamentos teológicos ou projetos ideológicos que se entrelaçam dentre as estruturas discursivas e sócio-históricas que definem o ato de compor.
\end{abstract}

Palavras chaves: Significação musical. Retórica, tópicas. José Maurício Nunes Garcia. Motete. Música no Brasil colonial.

\begin{abstract}
Inserted in the research line dedicated to the study of musical signification and, as part of a research project of the master's program in musicology of the School of Communication and Arts of the University of São Paulo (USP), this article proposes to investigate the importance of this knowledge/practice in the definition of the genre itself, the motete. This is because, the essence of this genre has in the word its core. As a starting point we will study the motete "Judas mercator pessimus" by Fr. José Maurício Nunes Garcia from the perspective of classical rhetoric, mainly based on topical theory. Thus, we will try to understand and demonstrate the behavior of the discursive structures of music and how its expression, through signification, comes to relate to the propositions of the text. Finally, we
\end{abstract}


will try to observe at what point the musical structures are in resonance with the structures of thoughts (mentalities and ideologies) and, in the present case, what would be the theological bases or ideological projects that are intertwined within the discursive and sociohistorical structures that define the act of composing.

Keywords: Musical meaning. Rhetoric, topical. José Maurício Nunes Garcia. Motet. Music in colonial Brazil.

\section{Introdução}

A considerar a tradição do motete enquanto gênero de expressão fulcral para o espetáculo litúrgico cabe a nós investigar e discutir o espaço ocupado pela música no âmbito da significação da palavra. É, sobretudo, um trabalho de interpretação que nos leva a considerar as estratégias retóricas e usos dos estilos usados pelo compositor.

O presente artigo visa observar o motete "Judas mercator pessimus" de Pe. José Maurício Nunes Garcia (1767 - 1830) para compreender estratégias de significados musicais que a sustentam como discurso. Consideramos para tanto que, como mestre-de-capela, sua música deveria desempenhar ao menos três funções: de cumprir com o decoro litúrgico; de proporcionar a experiência estética da música; de fazer do texto musical um campo argumentativo dramático para a edificação da assembleia.

Assim, o objetivo desse artigo concentra-se, primordialmente, nesta última função da música de José Maurício, ou seja, aquela na qual a música assume um lugar de fala como discurso. Isso significa, não só a expressão de uma técnica e ideologia, mas a compreensão de ferramentas para a oratória de seu tempo, no caso a retórica. É sob essas estruturas que a estrutura musical assume não só uma expressividade, mas se define "no" lugar de escuta, isto é, num espaço público onde dogmas, pragmáticas e hierarquias diversas estão em negociação permanente com as estruturas de mentalidades das épocas coevas e seus projetos políticos.

Nesse sentido, à guisa de introdução, esse texto tratará de equacionar as escolhas das retóricas tópicas de José Maurício tratando de vincular sua ideia musical a aspectos de seu capital simbólico. Por esse caminho que tratamos o que é fundamental na nossa pesquisa: desvelar o trato da linguagem musical, e de suas estratégias de composição, para analisar estruturas discursivas diante de 
MUSICA THEORICA Revista da Associação Brasileira de Teoria e Análise Musical 2018, v. 3, n. 2, p. 159-188 - Journal of the Brazilian Society for Music Theory and Analysis@ TeMA 2018 - ISSN 2525-5541

suas vivências e crenças. Sobretudo trata-se de uma análise dentro de uma história das mentalidades e de suas manifestações ideológicas.

Especificamente, esse texto trata de aspectos que estão nos entreatos da música. De forma introdutória, podemos adiantar que determinados aspectos da escrita musical induzem a uma interpretação sobre ambiguidades que poderiam estar amparadas na sensibilidade no discurso tradicional sobre Judas Iscariotes. Este personagem bíblico, no senso comum, se consubstancia por afetos cunhados no estigma do ato de traição a Cristo.

Justamente este será nosso foco de análise, ou seja, como José Maurício trata a questão. Já que, em vez de reforçar de modo austero os aspectos baixos da personagem, ou expressar clemência ou pena, levantamos a hipóteses da música de Pe. José Maurício lançar dúvidas, incertezas, resignação e até mesmo compaixão no trato da cena da Santa Ceia. $\mathrm{O}$ faz pela composição dentro de um afeto que poderíamos chamar de clemência, dentro de uma perspectiva discursiva da redenção mariana. Isso porque, como trataremos de demonstrar, trabalhando por justaposição ou sobreposição de elementos expressivos prédefinidos-as tópicas retóricas de ombra e pastoral-José Maurício organiza um argumento que foge ao senso comum, ou pelo menos causa estranhamento aos ouvidos contemporâneos.

Por fim, discutiremos como este afastamento da tradição pode causar questionamentos teológicos a partir da música a ponto de produzir uma pergunta: para José Maurício, Judas Iscariotes foi mesmo um infame mercador, ou estamos diante de um discurso que expõe a doutrina da salvação de forma ampla e irrestrita?

Por este caminho estabelecemos pelo menos duas linhas de pensamento, ao defrontarmos com o estado de dúvida e suspensão lançado pelo discurso musical em relação ao texto:

1. Pelo caminho do fundamento teológico, ou seja, por um discurso apoiado nas escrituras sagradas, dado que os quatro evangelistas, no texto da Paixão, apresentam narrativas divergentes em relação à ação de Judas.

2. Pelo caminho da mentalidade, ou seja, por um discurso que consubstancia a esperança da redenção oriunda da Mariologia, na qual todo pecador, até mesmo o pior deles-o próprio delator de 
Cristo-pode alcançar a salvação por intermédio da Virgem Maria e pela graça divina.

A metodologia se sustenta no entendimento da escrita a partir dos preceitos coevos da retórica, pois a consideramos a ferramenta sociocomunicativa da qual o compositor tinha conhecimento e perícia, assim como adesão estética por tradição cultural. A partir desse espaço, investigamos a inventio, lugar no qual são definidos os elementos que compõem o discurso musical a partir do afeto; como trataremos de demonstrar, dois elementos, a tonalidade e a métrica, logo no início assumem características ambíguas pela alteração de suas características como léxicos de campos expressivos predefinidos. Investigaremos também a disposição e organizado do discurso musical-a dispositio-para entendermos as estratégias dentro do "jogo" retórico, ou seja, a arte da argumentação, princípio fundamental da Ars Rhetorica. Por fim, como as figuras de retórica funcionavam na amplificação do discurso, perícia ligada ao ato da elocutio.

\section{Ars Rhetorica como espaço de natureza do conhecimento de José Maurício}

A compreensão da música passa pela dimensão cultural e intelectual do compositor. Não entraremos aqui nas questões biográficas de Pe. José Maurício, mas é útil olharmos no trabalho de Cleofe Person de Mattos (1997) alguns aspectos que dão sustentação a tese que discorreremos, fortemente amparada numa interpretação de textos bíblicos. Para tal, dentre muitos fatos desvelados pela musicóloga carioca, sublinhamos o depoimento transcrito de um importante orador brasileiro contemporâneo de José Maurício, Januário da Cunha Barbosa (1780-1846):

O grande músico [...] sabia ajuntar aos conhecimentos da sua Profissão favorita, outros não menos respeitáveis. [...] Estudou Retórica com igual aproveitamento, ouvindo as lições do Doutor Manoel Ignácio da Silva Alvarenga, e deu provas depois de que estava senhor dos preceitos de eloquência e de que sabia usar deles na exposição de argumentos de Teologia, a que também se aplicou, em muitos e excelentes Sermões que pregou, depois de se ordenar de presbítero no ano de 1792 (apud Mattos 1997, p. 50 - 51).

Este testemunho nos desvela um detalhe: o discurso musical de José Maurício se potencializa sempre numa plataforma teológica. Porém, isso seria 
MUSICA THEORICA Revista da Associação Brasileira de Teoria e Análise Musical 2018, v. 3, n. 2, p. 159-188 - Journal of the Brazilian Society for Music Theory and Analysis@ TeMA 2018 - ISSN 2525-5541

uma dedução com falseamentos claros se não observássemos a obra musical. Esta constitui um verdadeiro testamento de sua capacidade de "juntar aos conhecimentos da sua profissão favorita", ou seja, a música e a prática religiosa, e que inúmeros trabalhos de Diósnio Machado Neto tratam de demonstrar. ${ }^{1}$

No entanto, e à guisa de sustentação teórica, e em breves palavras inclusive porque esse assunto já é domínio de um conhecimento consolidado, é sempre positivo recordar que a retórica na música está fundada na transposição das ferramentas discursivas da Ars Rhetorica. É, sobretudo, uma tradição vinculada ao pensamento filosófico da Antiguidade Clássica e que sedimenta saberes que vão de Aristóteles, Cícero e Quintiliano até pensadores setecentistas como o português Manuel do Cenáculo (1724-1814).

Outra afirmação genérica, mas pertinente, é que a transposição dos conceitos retóricos para a música era inerente ao próprio conceito de música, desde a Antiguidade, porém consolidou-se como estética sobretudo na obra de autores germânicos do universo luterano, sempre preocupados com a relação entre a arte sonora e os processos de comunicabilidade do discurso literário. No entanto, o domínio da arte retórica, na música, espalha-se pela Europa católica e torna-se um domínio fundamental da prática musical, inclusive no Novo Mundo. ${ }^{2}$

O princípio básico é que na constituição do pensamento musical, a retórica atua em diversos campos, sempre buscando argumentos que provoquem a adesão da escuta tanto por causar verossimilhança e/ou envolver o ouvinte pela emoção. Seja como for, todo o processo ocorre pelo reconhecimento/ compartilhamento da linguagem, ou seja, pela audição que reconhece os lugares comum das estruturas musicais.

Na questão poética, a composição da época de José Maurício assimilou o uso de campos tópicos oriundos da prática da ópera veneziana do século XVII.

\footnotetext{
${ }^{1}$ Confira, entre outros, Diósnio Machado Neto, A manifestação do Iluminismo Católico em José Maurício Nunes Garcia: a Missa de Nossa Senhora da Conceição (1810). In: Diósnio Machado Neto, David Cranmer. (Org.). Música, Cultura e Identidade no bicentenário da elevação do Brasil a Reino Unido. 1ed. Lisboa: Caravelas - Núcleo de Estudos da História da Música Luso-Brasileira, 2016, p. 132-151. Idem, A arte do bem morrer: O discurso tópico na Sinfonia Fúnebre de José Maurício Nunes Garcia. Revista Portuguesa de Musicologia, v. 4, 2017, p. 33-66.

${ }^{2}$ Confira em Christovam, Ozório \& Machado Neto, Diósnio. A Retórica no ambiente musical lusobrasileiro. In: Matte, Iara \& Coelho, Maria Cecília (orgs.). Anais da IV Semana de Música Antiga da UFMG: bizzarie alegórica. Belo Horizonte: UFMG: Faculdade de Filosofia e Ciências Humanas, 2014, p. 66-77.
} 
Isso incluía a ideia de ornatos, que era o uso de gestos musicais padronizados que acentuavam determinado ponto do discurso, as chamadas figuras de retórica. Da mesma forma, retórica também envolvia a forma musical. Isso porque, o pensamento retórico ajusta os "suportes formais" (binário, ternário, concerto e fuga) aos procedimentos do desenvolvimento do argumento. A forma musical, por esse processo epistêmico, estaria "condicionada" aos mesmos processos de construção de discurso na literatura. Isso significa, na prática, que a composição estava vinculada, principalmente, a três estágios primordiais: inventio, dispositio e o elocutio. Nesse processo, a principal questão era a relação dos topici da "invenção" (lugares comuns da expressão) com os processos de desenvolvimento, ou seja, as estratégias para o desenvolvimento do argumento (dispositio).

Nesse sentido, os modelos formais pré-existentes se tornavam apenas suportes. Isso porque, as "estratégias" extrapolavam as amarras formais pela sua própria inerência vinculada à expressão. Em outras palavras, as estratégias estabelecidas no jogo da argumentação alteravam as formas-tipo a tal ponto de podermos pensar em gêneros vinculados à expressão. ${ }^{3}$

Em síntese, nem a forma musical, nem a estrutura retórica seriam determinantes para o discurso musical, e sim “os meios possíveis de persuasão

\footnotetext{
${ }^{3}$ Mark Evan Bonds desenvolve essa questão em Wordless Rhetoric: Musical Form and the Metaphor of the Oration (1991). Um dos problemas abordados por Bonds trata da relação entre forma e retórica. Uma das teses de Bonds foi que nos nossos tempos a leitura dos textos de Johann Mattheson nos induziu a erros, quando tratamos de relacionar diretamente a ideia da construção retórica ciceroniana com a música: "It is not to be equated directly to Mattheson's well-known but widely misunderstood attempt to draw parallels between the form of a musical movement and the structure of an oration (exordium, narratio, propositio, and so on)", mas, "that Mattheson's outline represents only one manifestation of a rhetorical conception of form" (Bonds 1991, p. 5). Não deve ser equiparado diretamente à conhecida, mas, amplamente mal entendida tentativa de Mattheson de traçar paralelos entre a forma de um movimento musical e a estrutura de uma oração (exordium, narratio, propositio e assim por diante)", mas, "que o esboço de Mattheson representa apenas uma manifestação de uma concepção retórica da forma" (Bonds 1991, p. 5). (Tradução dos próprios autores). Para Bonds a visão da música que prevaleceu a partir do século XIX, ou seja, a ideia da música como uma "metáfora orgânica", na qual os termos musicais e a forma musical ganharam autonomia, foi determinante para o entendimento de Mattheson. Explica que, no período galante, a música estaria condicionada pela "metáfora retórica", ou seja, a estrutura da música, inclusive sua forma, era determinada por um pensamento do desenvolvimento dos argumentos pelas leis da retórica e não pela determinação de esquemas. Seriam as estratégias de escolha e disposição dos campos musicais na exposição de um argumento o ponto fulcral do processo, fosse ele apenas em relação ao jogo entre os campos (arabescos entre opostos) ou mesmo construindo metáforas musicais de ideias.
} 
MUSICA THEORICA Revista da Associação Brasileira de Teoria e Análise Musical 2018, v. 3, n. 2, p. 159-188 - Journal of the Brazilian Society for Music Theory and Analysis@ TeMA 2018 - ISSN 2525-5541

em referência a qualquer assunto" (BONDS 1991, p. 5). Assim sendo, a retórica diz mais respeito à razão e ao saber sobre as estratégias discursivas do que a um conjunto estrito de regras ou ferramentas para tal,

Uma boa parte do problema, ao que parece, está na natureza da retórica, que, à sua maneira, engloba uma gama ainda mais ampla de ideias do que "forma" em si. [...] Nesse sentido, forma é a maneira pela qual o conteúdo de uma obra é tornado inteligível para seu público. Padrões convencionais, fornecendo aos ouvintes pontos de referência e previsibilidade, facilitam a apresentação de um conteúdo que necessariamente varia de trabalho para trabalho. [...] Quando vista sob essa luz ampla, a metáfora da obra musical como uma oração, [...] fornece um meio pelo qual forças internas, generativas, podem ser reconciliadas com convenções externas. (Bonds 1991, p. 5). ${ }^{4}$

A afirmação de Bonds remete a música à tradição literária ocidental. Usando a ideia de jogos de argumentos formou-se a possibilidade de escrever música dentro de padrões da tragédia ou comédia, usando metáforas musicais. Nesse sentido, pesquisas como de Robert Hatten (1996) apontam para a existência de gêneros expressivos, ou seja, gêneros que estariam sobre suportes formais, mas que teriam como objetivo transcender a forma:

Os gêneros expressivos, como o trágico para o transcendente, são, em certo sentido, os maiores tipos encontrados em um estilo. Como é o caso de formas como a sonata, elas também funcionam como esquemas, mas em um nível mais arquetípico. Como esquemas, eles direcionam uma ampla gama de diferentes eventos e suas interpretações, sem especificar resultados precisos em termos de design formal (Hatten 1994, p. 69). ${ }^{5}$

Seguindo na trilha desbrava por Hatten (1994), seria nesta perspectiva que a retórica teria sua principal função: aproximar a música dos modelos enraizados

\footnotetext{
${ }^{4}$ A good part of the problem, it would seem, lies in the nature of rhetoric, which in its own way encompasses an even broader range of ideas than "form" itself. [...] In this sense, form is the manner in which a work's content is made intelligible to its audience. Conventional patterns, by providing listeners with points of reference and predictability, facilitate the presentation of a content that necessarily varies from work to work. [...] When viewed in this broad light, the metaphor of the musical work as an oration, [...] provides a means by which internal, generative forces may be reconciled with external conventions (Ibidem).

${ }^{5}$ Expressive genres such as the tragic-to-transcendent are, in one sense, the largest types encountered in a style. As is the case for forms such as sonata, they also function as schemata, but at a more archetypal level. As schemata, they direct a wide range of different events and their interpretations, without specifying precise outcomes in terms of formal design (Hatten 1994, p. 69).
} 
de organização do pensamento, e sua expressão afetiva pelos tipos literários, como a Pastoral, o Trágico, o Épico, a Comédia, etc. Não só isso, ampliar seu alcance pelos gêneros híbridos no século XVIII, como o Tragicômico, o Trágicotranscendental, a Abnegação. Para tanto, os estilos-tipos eram modificados pela presença de elementos de "fora" de sua linguagem. Ou seja, primeiro haveria que reconhecer quais seriam os léxicos que formariam a linguagem para depois observar como eles seriam trabalhados, não só dentro das formas-tipo, mas principalmente pelas estruturas de "colisão" dos léxicos de diversos campos expressivos dentro de um campo expressivo específico. ${ }^{6}$

Desta forma, podemos dizer que os gêneros, tópicas-retóricas (que subordinavam as métricas, tonalidades e harmonias, orquestração, fluxos rítmicos e melódicos) e figuras retóricas eram estruturas pré-composicionais que tratavam de metaforizar realidades sentidas e vividas. E estas metáforas assumiam estruturas retóricas diversas, desde formas fixas como as árias e minuetos até os gêneros expressivos.

E José Maurício Nunes Garcia não estava fora desse campo conceitual, aliás, era a sua própria mentalidade, apesar de viver nas bordas do mundo ocidental, ou melhor, nos espaços onde a razão ocidental era estabelecida como paradigma de estrutura social colonizada.

\section{Judas na tradição religiosa e a leitura de José Maurício Nunes Garcia}

Quando tratamos de processos de significação musical atrelados à tradição musical antiga, e da música religiosa, sempre é necessário ter em mente a natureza dos argumentos, sua tradição na composição e, por fim, quais são as

\footnotetext{
${ }^{6}$ Campos expressivos são estruturas simbólicas complexas (constituída por vários elementos icônicos-léxicos-que assumem a função de representar paisagens, sentimentos ou ações humanas como o campo, a tempestade, o militar, o heroico, a caça, etc). Estes campos são passíveis de serem reconhecidos através de uma retórica dos estilos cristalizadas nas tradições dramáticas da música (desde as canções de gesta até a ópera). O principal teórico da ideia de uma música organizada por campos expressivos foi Leonard Ratner. Este tratou de taxonomizar uma linguagem musical considerando o uso de categorias reconhecíveis e que poderiam ser discriminadas como estilos (campos simbólicos complexos como a pastoral), tipos (gêneros fixos como as danças) e word-painting (gestualidades como o lamento). Ademais, reconheceu que estes estilos estariam subordinados a uma perspectiva de correlação com lugares de fala (dignidades) e lugares de escuta (ambientes), criando estilos de enunciação dentro de um mesmo campo expressivo: baixo, médio e alto.
} 
MUSICA THEORICA Revista da Associação Brasileira de Teoria e Análise Musical 2018, v. 3, n. 2, p. 159-188 - Journal of the Brazilian Society for Music Theory and Analysis@ TeMA 2018 - ISSN 2525-5541

práticas discursivas em jogo, diante das forças sócio-históricas envolvidas no processo de recepção. Poderíamos chamar esse processo de práticas discursivas.

Para o nosso problema, é importante entender que a passagem da Paixão que relata o ponto culminante da cena entre Jesus e Judas Iscariotes se apresenta de modo variável nos livros dos quatro evangelistas do Novo Testamento: Mateus, Marcos, Lucas e João.

O texto de Lucas (Lc XX, 21-23) oferece poucos detalhes sobre Judas, ao contrário de João (Jo XIII, 2), o mais minucioso e controverso dos quatro evangelistas. João atribui ali a ação de Judas à influência de Satanás. No desfecho, ao narrar a fala de Jesus, reforça esta influência quando diz "o que fazes, faze-o depressa", como se tal ato viesse a configurar uma espécie de envio, que seria o estopim para o plano de redenção da humanidade que havia de se cumprir. Mateus (Mt XXVI, 20-25) preserva uma narrativa na qual Cristo se refere a Judas de maneira mais austera. Por sua vez, Marcos (Mc XIV, 17- 21) se assemelha àquela de Mateus, mas com menor riqueza de detalhes.

Sobre esses evangelhos é que se formou o responsório para a Quinta-Feira Santa, provavelmente ainda nos primeiros séculos da Igreja Católica. Também, há uma tradição de que o texto teria surgido dentro de escritos antissemitas do século XI e XII.

\begin{tabular}{|l|l|}
\hline Texto Orginal & Tradução \\
\hline Judas mercator pessimus & Judas, vil mercenário \\
Osculo petitit Dominum & Exigiu um beijo do Senhor \\
Ille ut agnus innocens & Este, como cordeiro inocente \\
Non negavit osculum Judae & Não negou o beijo a Judas \\
Denariorum numero & Por algumas moedas \\
Christum judae is tradidit & Entregou Cristo aos judeus \\
Melius illi erat & Melhor seria \\
Si natus non fuiset & Que não tivesse nascido \\
\hline
\end{tabular}

A questão da origem do texto, no entanto, é menor em relação à tradição festiva a qual ele se associa, e tudo o que dela se extrai de simbolismos. No que diz respeito ao espetáculo da religiosidade popular na qual, também, a Paixão de Cristo se consubstancia, vemos que no Brasil, por exemplo, se preserva a cultura de "malhar o Judas" na manhã do sábado seguinte à sexta-feira da Paixão. Parece haver nesta prática certa manutenção de um veredito arbitrário que condena veemente a figura do discípulo traidor, ao ponto do nome de Judas perder a função de substantivo a tornar-se adjetivo associado a todo tipo de traição e ato 
mercenário. Logo, nossa expectativa sobre um compositor consciente de sua posição como orador sacro é de uma leitura disfórica dessa passagem da Paixão.

No entanto, historicamente nem sempre isso se justificava. Isso porque, determinadas doutrinas, como a Mariologia do século XVIII, poderia se impor a tal ponto de suscitar a interpretação da traição de Judas por um complexo conceito teológico: a redenção. Inclusive, porque as próprias escrituras não disseminam com clareza um veredito de traição à Judas Iscariotes, além do fato de que segundo a Mariologia, todo pecador é merecedor da graça divina, da misericórdia de Deus. Assim, para compreender os simbolismos em níveis discretos há que buscar a interpretação possível do personagem, em relação ao local da cultura. Até porque, Judas é um personagem que pode suscitar, por si só, um dos nós górdios do cristianismo: a infinita amplitude do perdão.

Assim sendo, o compositor, dependendo das forças discursivas e suas amarras sociocomunicativas, poderia fazer diversas leituras, inclusive pela pedagogia da salvação. Desta forma, seria justificável que os recursos e estratégias para dar significação musical a esse problema buscassem certas ambiguidades na formação de seus simbolismos. Por isso a questão do Mariologia recobra importância.

Evidentemente a matriz do marianismo no Brasil se deve ao catolicismo português. Apenas para se ter uma dimensão do impacto dessa doutrina basta dizer que o marianismo fazia parte até mesmo da alta política de Estado. A própria fundação do Estado português, por Dom Afonso Henriques (1139), consagrou o reino de Portugal à Maria. Em 1640, D. João IV ratificou o ato de D. Afonso Henriques e proclamou a Virgem da Conceição padroeira de Portugal e todas as suas possessões, inclusive o Brasil. Em síntese, a devoção a Maria era então uma prerrogativa de dinastia no reino português (Cipolini 2010, p. 40).

Por esses, e outros caminhos, a Mariologia tornou-se um espaço de práticas socioculturais de profundas raízes. De tal forma, que a convicção redencionista constituiu-se no decorrer da tradição cristã como podemos ver no impacto de crenças sobre a Boa Morte ou o Bonfim. Especificamente no século XVIII acreditava-se que pelo poder intercessor da Virgem todo pecador poderia alcançar a salvação, mais que isso, criou-se uma mensagem de otimismo da redenção.

Em nossa análise, é justamente o aspecto misericordioso depositado na figura de Maria como "advogada e medianeira” da obra redentora de Cristo que 
se apresenta como pano de fundo no argumento de Pe. José Maurício, especialmente em Judas mercator pessimus. Aliás, essa era a perspectiva de um dos teólogos de maior impacto na segunda metade do século XVIII, São Luís Maria Grignion de Montfort (1673-1716). Diz Montfort: "É tão caridosa que não repele nenhum dos que pedem a sua intercessão, por mais pecador que seja" (Monfort 2007, p. 71). No motete de José Maurício parece ser esta a leitura: uma mensagem de redenção até mesmo de um traidor.

\subsection{A inventio}

Ao avançar em nossa análise da inventio trataremos de demonstrar como os elementos expressivos foram escolhidos pela necessidade do discurso: a questão da redenção mariana diante da traição de Judas.

A primeira escolha que chama atenção no motete de José Maurício é justamente a tonalidade de Mi, maior. Segundo Machado Neto, "para os autores do final do século XVIII, como Schubart e Galeazzi, o Mi, maior era a tonalidade usada tanto para passagens solenes e majestosas, como para expressar intimidade com a divindade" (Machado Neto 2015, p. 138). Já Ratner (1980) comenta que a tonalidade de $\mathrm{Mi}$ b maior também era uma tonalidade propícia ao estilo militar, por ser esta uma tonalidade favorável aos instrumentos da família dos metais. Considerando assim, o Mib maior parece ser uma tonalidade propícia às dubiedades. E José Maurício parece consciente dessa propriedade, como veremos adiante.

Outra questão é da métrica. Não deixa de ser peculiar, ou menos usual, não só o modo maior, mas, também, a métrica ternária (Exemplo 1). Isso porque, na prática dos compositores italianos e ibéricos (Exemplo 2), este texto é predominantemente musicado no modo menor, em métrica binária com ritmo básico dátilo seguido de um anapesto (métrica muito usada em hinos).

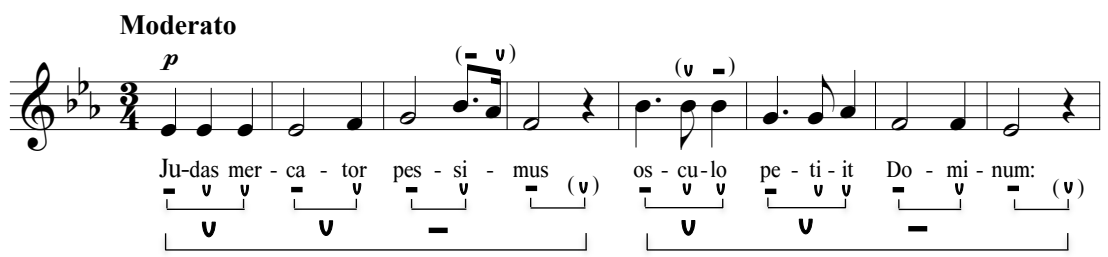

Exemplo 1: exordium do motete Judas Mercator Pessimus - agrupamentos rítmicos de dátilo e anapesto. 


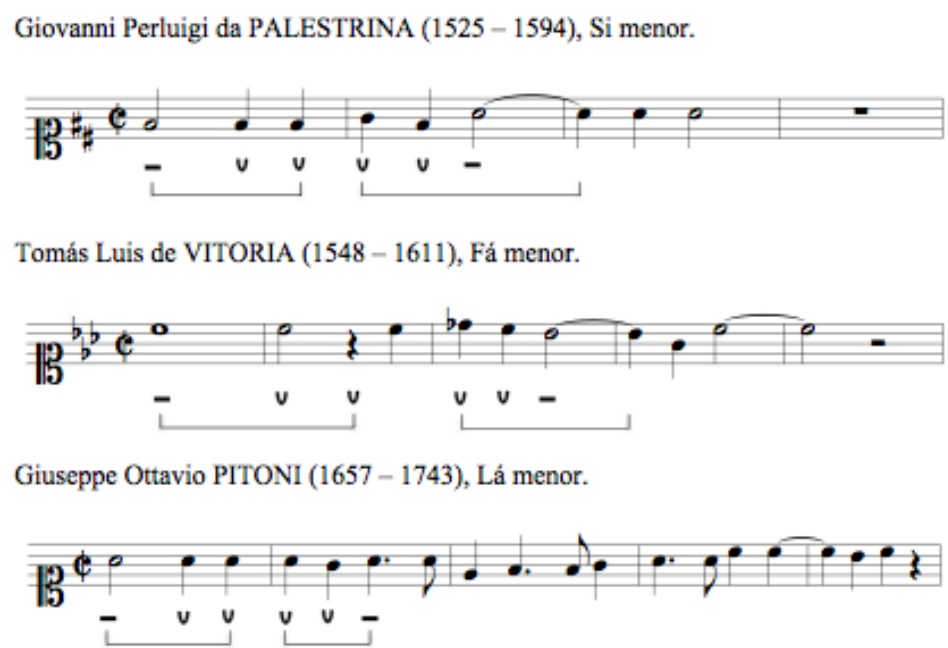

Marc'Antonio INGEGNERI (c.1535 - 1592), Mi menor.

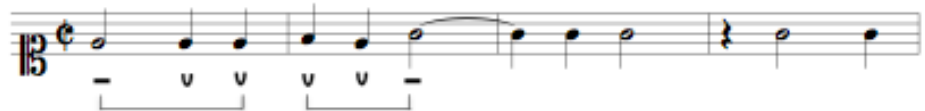

Exemplo 2: Judas mercator pessimus - incipt das composições de Palestrina, Vitoria, Pitoni e Ingegneri.

No entanto, a questão da métrica é mais complexa do que simplesmente ver sua natureza (binária ou ternária) e os pés métricos constituintes. É necessário termos em mente a distinção e a independência dos parâmetros pulso, métrica e ritmo, tanto quanto seus respectivos entrelaçamentos.

Grosvenor Cooper e Leonard Meyer (1960) analisam o ritmo a partir de uma estrutura arquitetônica existente em três níveis: inferior, primário e superior. Nos três níveis encontramos basicamente agrupamentos rítmicos oriundos da tradição de associação com a prosódia, isto é, os pés métricos da tradição poética da Antiguidade Clássica. Os autores também ressaltam o papel da mente na ação interpretativa do ritmo e daí sua condição de ambiguidade por se tratarem de "similaridades e diferenças, proximidades e separações de sons percebidos pelos sentidos e organizados pela mente."

Os agrupamentos podem as vezes ser intencionalmente ambíguos (grifo nosso) e devem ser então entendidos ao invés de forçados a um claro e decisivo padrão. Em resumo, a interpretação da música-e é isso que a análise deve ser-é uma arte que requer experiência, compreensão e sensibilidade (Cooper e Meyer 1960, p. 9). ${ }^{7}$

\footnotetext{
${ }^{7}$ Grouping may at time be purposefully ambiguous (grifo nosso) and must be thus understood rather than forced into a clear decisive pattern. In brief, the interpretation of music-and this is
} 
Na instância primária da invenção, o compositor propõe uma melodia bastante complexa na questão métrica. Primeiro, como já dissemos, obedecendo ao decoro da função desse motete, José Maurício escolhe uma métrica adequada para momentos de forte introspecção, o dátilo (veja Exemplo 2).

Como já demonstrado em tantos artigos sobre estudos tópicos desenvolvidos no Laboratório de Musicologia da EACH-USP, o dátilo é uma métrica que serve para marchas fúnebres, para momentos de transcendência ou heroico (hexâmetro dátilo), ou para situações de severa gravidade, como um solilóquio sobre um destino trágico. Cabe ainda dizer, que a audição contemporânea dessas métricas é desafiada por não termos o capital simbólico com o qual possivelmente os ouvintes dessa época tinham. Isso porque, não precisariam de mais compassos para entender o simbolismo do dátilo. Aliás, não pensariam em dátilo, apenas que estariam na expectativa de escutar algo fúnebre ou terrificante, na qual o dátilo se presta. Assim é, as três notas repetidas funcionam aqui para impulsionar a ideia de marcha, no caso uma marcha de característica penitencial, inclusive pelo coro em uníssono.

No entanto, enquanto o ritmo no nível primário se constitui no pé métrico dátilo, no nível superior há um sentido mais amplo de anapesto. É desta forma, que a organização rítmica de Pe. José Maurício trata de camuflar os dois agrupamentos rítmicos (dátilo e anapesto), respectivamente nos planos primário e superior: o compasso está em dátilo e a semifrase em anapesto. Isso, de certo modo remeteria a um diálogo com a tradição dos motetes sobre o tema, como podemos ver no Exemplo 2, ao mesmo tempo que daria suporte a um discurso de ambiguidade. Enquanto o dátilo é um metro de severa gravidade, o anapesto é típico dos hinos, ou pelo caráter galopante, das poesias de caráter rústico.

Logo, no domínio da significação das notas repetidas, José Maurício compõe a melodia expondo sutilmente os campos expressivos através de uma distribuição métrica fundamental para o jogo tópico: a base rítmica cria as condições futuras da ombra (pé métrico dátilo se presta a isso) e a linha melódica a pastoral (pelas duas semifrases em anapesto).

what analysis should be-is an art requiring experience, understanding, and sensitivity (Cooper e Meyer 1960, p. 9). 
Porém, José Maurício vai além na "mistura". Rapidamente ambientando ao decoro, pelos dois compassos iniciais, José Maurício apresenta sua tese. Quebrando a primeira expectativa do lugar comum, o compositor "insere" na incipiente marcha duas gestualidades que quebram a expectativa a partir do terceiro compasso: o salto de terça de Sol-Si b e de Láb-Fá, associado ao ritmo pontilhado. Essa pequena gestualidade (levare do c. 4) (Exemplo 1) reafirma o que a métrica subliminar (nível superior) já tinha indicado: uma sonoridade binária pastoral, em anapesto, o pé métrico afeito a representação do rústico. Mais que isso, se olharmos com atenção no colchete 1 podemos perceber o desenho melódico de uma dança rústica; e pelo colchete 2 uma siciliana, ou ao menos um simulacro, considerando que é uma pastoral siciliana escrita em 3/4, e não em 6/8 como era sua natureza (Exemplo 3).

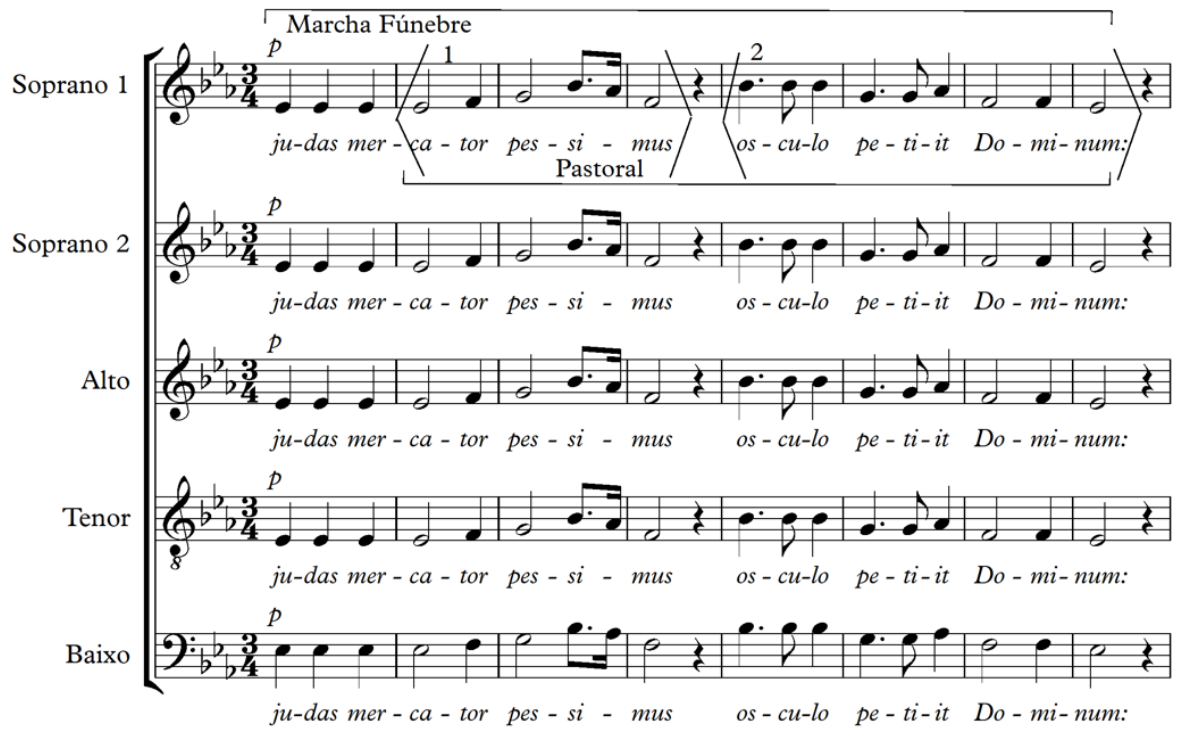

Exemplo 3: Judas mercator pessimus - exordium

Esta é a instância média da significação, ou seja, reconhecer as métricas, as gestualidades e o campo expressivo geral. No entanto, há um jogo oculto determinado pela tropificação. No caso do motete em questão, como já afirmamos, há uma sobreposição de duas tópicas: ombra (especificada desde o início pela sugestão de marcha penitencial) e a pastoral (no caso uma pastoral siciliana, apesar da célula de dança rústica), construídas desde as escolhas da métrica e do ritmo.

Vejamos agora com mais detalhe como se dá a percepção da ombra, inclusive o leve traço de marcha penitencial, que determina o andamento e, 
MUSICA THEORICA Revista da Associação Brasileira de Teoria e Análise Musical 2018, v. 3, n. 2, p. 159-188 - Journal of the Brazilian Society for Music Theory and Analysis@ TeMA 2018 - ISSN 2525-5541

consequentemente, ambienta a pastoral siciliana, principalmente no que diz respeito ao tempo lento.

Primeiro há que se dizer que a marcha penitencial é uma instância implícita, na medida que a pastoral siciliana é o nível explícito do campo expressivo. No entanto, não fosse por ela, a marcha, o argumento ficaria sem a sustentação da ombra, o que tiraria a matiz da introspecção que o decoro da cerimônia impunha.

No entanto, para perceber a marcha é preciso fazer um simulação na melodia do exordium (Exemplo 4). Omitindo o ritmo pontuado e suprimindo a nota $\mathrm{Si}$, ou seja, transformando o Láb, como nota de passagem (em semínima) para o Sib (suprimindo o quarto compasso), o trecho fica absolutamente compatível com uma marcha. Inclusive poderia se configurar numa marcha fúnebre se José Maurício quisesse. Para tanto, seria necessário apenas intensificar com figuras de pathopoeia e controlar a austeridade do desenho melódico. Porém, o próprio contorno em arco da melodia é bastante sugestivo de um outro tipo de marca, a marcha penitencial.

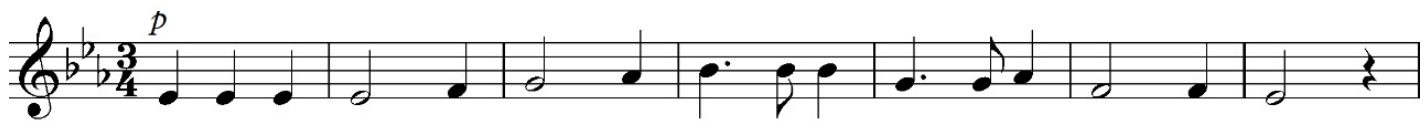

Exemplo 4: simulação da melodia sem a célula rítmica de dança

Porém, José Maurício não fez escolha na direção de uma marcha penitencial pura. $\mathrm{O}$ ritmo pontilhado em salto de terça marca (especifica) toda a melodia, inclusive indexando o dátilo dos compassos seguintes dentro de um espírito pastoral siciliana (Exemplo 1).

Em síntese, não só pela tonalidade e escolhas do planejamento rítmico, a inventio de José Maurício indica uma leitura da passagem bíblica a partir de um jogo complexo de sentidos ambíguos. As escolhas tópicas também foram elencadas para criar esse ambiente de questionamento sobre a famosa passagem da Santa Ceia, justificado, relembramos, por um momento de grande tensão onde o cordeiro de Deus (simbolizado na pastoral) reconhece o destino sacrificial na pessoa de Judas (simbolizado na ombra). Ademais, nos sentidos das escolhas podemos tirar conclusões sobre o próprio afeto, que é o cerne daquilo que se deseja comunicar. Duas categorias de afeto estão presentes neste motete, observando as escolhas do material musical: commiseratio et lacryma, que 
justificaria a escolha pela ombra e pastral siciliana; e furor et indignatio, pela presença de uma marcha que por vezes se apresentara como tópica marcial, inclusive com toques de trombeta (Exemplo 5) que não só acusam a traição de Judas, mas também remetem a reflexão. E a articulação desse processo se dá na perícia para a miscelânea do material pré-composicional.

\subsubsection{A questão da pastoral siciliana}

Na questão discursiva, a determinação do loci topici é fundamental. Num ambiente de dignidade religiosa, e, principalmente, na Semana Santa, o lugar comum da fala impunha a observância de inúmeras pragmáticas em observância às dignidades das cerimônias. Ademais, nesse ambiente era necessário um jogo erudito de citações, intertextualidades e uso de um capital simbólico para criar discursos que não só quebrassem o decoro imposto, mas, e principalmente, elevasse a dimensão emocional do espetáculo litúrgico.

Dito isso, é evidente que o argumento de José Maurício buscava questionar alguns pontos da narrativa tradicional, sustentado possivelmente por novas posturas diante da questão da penitência e redenção. Isso, justificaria, primeiro, o compositor não ter optado por uma ombra escolar, pois esta levaria a questão da condenação de Judas distante do argumento central da obra, que se desvela no tropificar da marcha penitencial com a pastoral.

Por isso, é importante termos claro dois aspectos, aqui reiterados: se não fosse a gestualidade de dança rústica do levare do quarto compasso todo o trecho poderia ser ouvido como marcha (e dependendo da harmonia subsequente ao exordium, uma marcha fúnebre). No entanto, essa gestualidade dá ao compasso cinco, em diante, a característica de pastoral siciliana. Por outras palavras, é a gestualidade de dança rústica, como já dissemos, que indexa todo o ambiente para sustentar a pastoral siciliana.

A questão é: a pastoral siciliana seria contrário ao decoro de um motete de Semana Santa? A resposta é não. Essa tópica se tornou um campo expressivo dentro de ambientes de constrição religiosa, inclusive estando presente em inúmeras árias das cantatas e paixões de Bach, quando o tema era a morte:

A crença no paraíso como o destino da vida humana levou à uma conexão inesperada, aquela do pastoral com a morte. Esta nos lembra a associação do amor platônico com a morte, o tema de "Eros funerário", nos tempos modernos a Liebestod (vide Wind 1967 [1958], p. 152-170). As cantatas de 
MUSICA THEORICA Revista da Associação Brasileira de Teoria e Análise Musical 2018, v. 3, n. 2, p. 159-188 - Journal of the Brazilian Society for Music Theory and Analysis@ TeMA 2018 - ISSN 2525-5541

Bach sobre morte são largamente isentas do sentimento de tristeza ou lamento (Monelle 2006, p. 232). ${ }^{8}$

Este estilo, feito normalmente em métrica de binário composto, tempos lentos com figuras pontuadas, "muitos deles em tonalidades menores" (Monelle 2006 , p. 217) sem a presença do baixo pedal - característica marcante do estilo pastoral - tinham textos que evocavam temas emocionais, lamentosos ou melancólicos como vimos na citação acima de Raymond Monelle. ${ }^{9}$ Mattheson afirmava que os compositores do século XVIII privilegiavam o tipo lento [de siciliano] porque havia neles "uma certa seriedade", adequado para "assuntos sensíveis e comoventes" (apud Monelle 2006, p. 214). Aliás, em seu Der Vollkommene Capellmeister (1739), faz referência a sentimentos de "ternura" e "nobre simplicidade" em referência ao estilo (Jung 1980, p. 150). Ademais, nas palavras de Monelle, "os suaves $12 / 8$ ou 6/8 da siciliana parecem fundamentais para o espírito pascal” (Monelle 2006, p. 214). Em outras palavras, a pastoral seria o campo simbólico importante para a ideia de redenção, de uma importante mensagem do tempo pascal: morrer para viver a vida eterna.

Dito isso, podemos concluir que José Maurício estava não só dentro da tradição, mas usou a pastoral siciliana de forma a reforçar a ambiguidade do seu discurso. Ademais, mesmo usando estratégias singelas, mas efetivas, como apresentar o argumento em monodia e assim criar uma expectativa no ouvinte sobre o "destino" da pastoral, José Maurício não só conseguia indexar todo a unidade musical como, também, pela quebra de expectativas, intensificar as tópicas. Isso fica claro na questão da tonalidade. O bom ouvinte esperaria a harmonização em menor, no entanto, surge o modo maior como espaço tonal protagonista. Outrossim, a escolha do tempo 3/4, ao invés do 12/8, é outra sutileza, pois dá à siciliana uma grande plasticida: tem aspecto de marcha, mas é uma pastoral. Aliás, esse trabalho ainda possibilita as fanfarras marciais, que ocorrem no fechamento das frases.

\footnotetext{
8 The belief in heaven as the destination of human life led to an unexpected connection, that of pastoralism with death. This may bring to mind the association of Platonic love with death, the theme of the "funerary Eros", in modern times the Liebestod (see Wind 1967 [1958], 152-170). Bach's cantatas about death are largely lacking in a sentiment of sadness or lamente (Monelle 2006, p. 232).

${ }^{9}$ A maior referência que se tem deste gênero é o compositor napolitano Domenico Scarlatti (1685 - 1757). "Com o sucesso das óperas de Scarlatti, a maneira pastoral siciliana se torna amplamente conhecida e é descrita nas enciclopédias musicais" [grifo nosso] (Monelle 2006, p. 219).
} 
Portanto, e dado o contexto da peça em análise, podemos dizer, em síntese, que no âmbito da significação o siciliano pode: 1) fornecer imagens mentais sobre o ambiente, a paisagem ou cenário que remete ao campo-o horto das oliveirasonde ocorre a trama; 2) expressar musicalmente as palavras do texto, no momento em que o estilo se define, sobre o caráter nobre e terno da personagem de Cristo, a vítima inocente em seu estado de melancolia, ou mesmo a ideia de redenção dos "puros de alma"; 3) fortalecer a ideia do compositor de ambiguidade, indecisão e oscilação dos sentimentos evocados através da manipulação do material elencado, por exemplo, o uso da pastoral siciliana em modo maior, o que confirmaria a própria ambiguidade como estratégia diante do estilo (uso de um token); 4) por fim, estabelecer o campo expressivo desta primeira parte: um siciliano tropificado com uma ombra criando uma estrutura sobre a qual se fiarão os argumentos embebidos de ambiguidade e oscilação afetiva.

\subsection{A dispositio}

Primeiro há que se dizer que em "Judas mercator pessimus", José Mauricio trata musical e formalmente dentro de uma tradição ibérica: o texto é dividido em três partes, sendo a segunda repetida de modo a finalizar a peça. $\mathrm{O}$ compositor faz de cada parte um movimento quase autônomo-uma unidade musical - , dado que a instabilidade harmônica cria suspensões ou resoluções não perfeitas a fim de criar um sentido de continuidade e interligar os três movimentos (Tabela 1).

A textura cumpre papel primordial, também para a dispositio. Ao longo dos movimentos promove uma intensificação da textura, a qual vai ficando cada vez mais densa em informações: moderato - uníssono, homofônico (pieno); fugato-paraa simular um contraponto imitativo/homofônico (apenas nas transições tonais); e larghetto-para simular um contraponto palestriniano. A métrica, por sua vez, também promove um certo alargamento: respectivamente ternário (3/4), binário (2/2) e quaternário (4/4). A harmonia em todos os movimentos é caracterizada por certa hibridez: modo maior/modo menor; região da tônica/região da dominante e sobreposição de ambas.

Porém um aspecto é fundamental para esse estudo: o discurso retórico. Em nossa interpretação, por este aspecto poderia se justificar uma assimétria em relação à forma do texto considerando que o último movimento, larghetto, se 
MUSICA THEORICA Revista da Associação Brasileira de Teoria e Análise Musical 2018, v. 3, n. 2, p. 159-188 - Journal of the Brazilian Society for Music Theory and Analysis@ TeMA 2018 - ISSN 2525-5541

apresenta como uma retomada da propositio (Tabela 1), ou seja, retoma o impulso inicial da obra.

No nosso entendimento, esse aspecto formal se dá na medida que a peça propõe uma narrativa sustentada numa visão que mitiga a rigidez de um senso comum estabelecido, ou seja, a condenação inapelável de Judas.

Nossa análise se centra no moderato (Tabela 1). Este não traz grandes novidades e segue uma constante na música de José Maurício: o uso de forma ternária. No entanto, a questão complexa nessa peça não é a formal, mas a construção discursiva que, tendo a forma como suporte, não a altera a ponto de não ser perceptível o molde.

\begin{tabular}{|c|c|c|c|c|c|c|c|c|c|c|c|c|c|c|c|c|}
\hline Partes & \multicolumn{6}{|c|}{ Moderato } & \multicolumn{6}{|c|}{ Fugato } & \multicolumn{4}{|c|}{ Verso Larghetto a 4} \\
\hline Texto & \multicolumn{6}{|c|}{$\begin{array}{l}\text { Judas mercutor pessimus / asculum petiit Dominum: ille ul agnus } \\
\text { inoccens / non negavit aculum Judae. }\end{array}$} & \multicolumn{6}{|c|}{ Denariorum numero Chistum Judae is tradidit. } & \multicolumn{4}{|c|}{$\begin{array}{l}\text { Melites illi enat / Si natus non } \\
\text { fuisset. }\end{array}$} \\
\hline Compasso & $1-8$ & $9-16$ & $17-32$ & $33-42$ & $43-50$ & $51-67$ & $1-10$ & $11-14$ & $14-23$ & $24-27$ & $27-43$ & $44-72$ & $1-4$ & $4-8$ & $8-10$ & $10-14$ \\
\hline Seçĩes & \multicolumn{2}{|c|}{$\mathrm{A}$} & \multicolumn{2}{|c|}{ B } & \multicolumn{2}{|c|}{$A^{\prime}$} & \multicolumn{2}{|c|}{$\mathrm{A}$} & \multicolumn{2}{|c|}{ B } & $A^{\prime}$ & & & & & \\
\hline & & $a$ & $b \quad a^{T}$ & $b^{\prime}$ & & $a$ & $a$ & $b$ & $a^{T}$ & $b^{T}$ & $a^{2}$ & & & & & \\
\hline Textura & Unissono & \multicolumn{3}{|c|}{ Homofonia ritmica } & Unissotho & Hoemofonia & 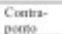 & $\begin{array}{l}\text { Houns- } \\
\text { finti: }\end{array}$ & $\begin{array}{l}\text { Couta- } \\
\text { Dareses }\end{array}$ & $\begin{array}{l}\text { Houns- } \\
\text { forie }\end{array}$ & Cuatra- & & & & & \\
\hline Harmonia & Mib malior & 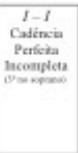 & 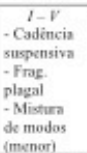 & 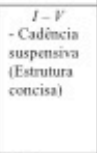 & & 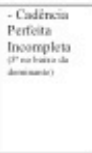 & 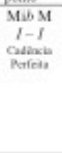 & 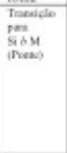 & 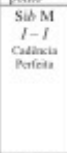 & 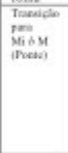 & 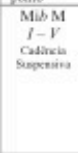 & $\begin{array}{c}\text { Hibridez } \\
\text { tonal } \\
I-1 \\
\text { Pedelna } \\
\text { Demimanse }\end{array}$ & $\frac{\sin M}{l-l}$ & $\begin{array}{l}\text { Dom } \\
\text { Pass } \\
\text { porr } \\
\text { Re m m }\end{array}$ & MibM & $\begin{array}{l}\text { SibM } \\
W-1\end{array}$ \\
\hline Métrica & \multicolumn{6}{|c|}{$\underset{3 / 4}{\text { Temário }}$} & \multicolumn{5}{|c|}{$\begin{array}{c}\text { Binario } \\
2 / 2\end{array}$} & & \multicolumn{4}{|c|}{$\begin{array}{c}\text { Quaternário } \\
\text { e }\end{array}$} \\
\hline $\begin{array}{l}\text { Dinâmicas } \\
\text { Articulap̧èes }\end{array}$ & $p$ & $p p$ & $f$ & $f / s f z$ & & $\begin{array}{l}P / m f / \\
\text { cress. } / p p\end{array}$ & $f$ & $p$ & $f$ & $p$ & $f$ & $P / f / f f$ & $p$ & $f / p$ & $p$ & $p$ \\
\hline $\begin{array}{l}\text { Tópicas } \\
\text { e } \\
\text { figuras } \\
\text { retóricas }\end{array}$ & Ombra & 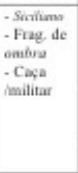 & 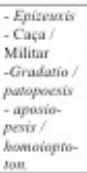 & $\begin{array}{l}\text {-Aponaperi } \\
\text { / suspiratio } \\
\text { - Paullogia }\end{array}$ & Ombra & 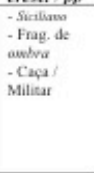 & 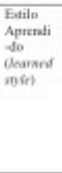 & Pieno & 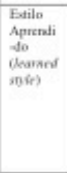 & Piema & 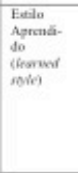 & 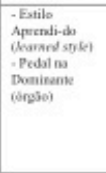 & 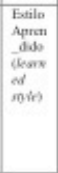 & & $\begin{array}{l}\text { Catirn: } \\
\text { pausto } \\
\text { eqpetie }\end{array}$ & \\
\hline
\end{tabular}

Tabela 1: dispositio de Judas mercator pessimus

O primeiro importante aspecto é compreender a função do coro em uníssono. De início, o canto remete a uma sonoridade monódica dos solilóquios, inclusive com desenho em arco típico da salmodia antifonal. Em outras palavras, um campo de severa gravidade. Em segundo lugar, essa monodia posterga o impacto da tonalidade, numa estratégia para prender a atenção da harmonia que virá. Por fim, o jogo oculto das tópicas no qual José Maurício, em poucos compassos, revela seu argumento. Diga-se de passagem, que aqui está uma das lições primordiais da retórica clássica: a exposição da ideia ganha a plateia quando consegue estabelecer a atenção pela forma como apresenta o argumento nos seus primeiros momentos.

A proposição da ambiguidade-uma pastoral siciliana num ambiente de ombra-é confirmada logo após o canto monódico. Primeiro, a melodia é 
afirmada na tonalidade de Mib maior, o que quebra a expectativa de um modo menor, inclusive para os que puderam perceber uma pastoral siciliana na métrica. Mais, apresenta-se num sentido eclesiástico, cujo pieno acentua um afeto amoroso (c. 9-16). Esse bloco, contraditoriamente, conclui por uma figura marcial (trombeta), reforçado pela dignidade penitencial da textura também em pieno. Isto não só reafirma a tonalidade, mas é eloquente na condenação de Judas, um vil mercador. 10

Toda essa tensão da figura de trombeta é reiterada, porém em modo menor (Dó maior). Essa estratégia joga com os estilos de forma exemplar. Primeiro que a trombeta se resinifica, mitigando o tom acusatório e nos induzindo a afetos disfóricos que poderiam ir da tristeza à inquietação do espírito do perdão universal, por nós negado ao condenar Judas.

Assim, caminhando pelos contrastes, o discurso da ambiguidade da redenção se define, Não só em instâncias como a hibridez métrica e rítmica caracterizado que, por contrastes e irresoluções, permeará toda a peça, mas, também pelo jogo das tópica: da pastoral siciliana sobreposta a uma ombra, que se desdobra num estilo eclesiástico em modo maior logo após a monodia e retorna em estilo marcial da indignatio. Enfim, José Maurício atende a lição da “oposição de espécies" 11 através dos elementos disfóricos dos afetos da categoria

\footnotetext{
${ }^{10}$ Monelle mostra que o universo da gestualidade militar, como vemos pelo uso da trombeta no fim da frase, está associada a uma diversidade de eventos no âmbito da vida cultural europeia, principalmente ao longo do século XVIII: a corte, a nobreza, o tribunal, o cívico, o cerimonial, o fúnebre, ou a figura do soldado associado ao masculino e à guerra. No entanto, no caso do motete do compositor carioca parece haver uma evocação bastante ampla do conceito militar, desde o marcial como afirmação de um conceito ou mesmo uma menção híbrida com a condenação (o tribunal), até a uma metáfora com a "caça ao Cordeiro inocente". Seja como for, essa célula funciona como uma figura de trombeta. Intensifica ainda mais a significação considerando o cenário da ação-o horto das oliveiras - e, mais ainda, a presença de soldados. Ainda seguindo Monelle, é dele a afirmação: "the ubiquity of military evocations in our music betokens a wideranging, varied, and very complex topic. As for the signifier, the two main aspects-the military march and the trumpet call-each has its own history, though they are closely intertwined" (Monelle 2006, p. 113).

11 Sobre a questão de "oposição de espécies" Machado Neto afirma: "apoiado nas discussões coevas sobre a natureza do movimento das emoções, que determinariam as questões de estilo, Silva Alvarenga [professor de Retórica do Pe. José Maurício] acreditava na transitoriedade dos elementos expressivos sustentada por relações de síntese, ou seja, a oposição das «espécies» poderia levar a um «outro» elemento expressivo, ou pelo menos ampliar o sentido da expressão. $\mathrm{Na}$ introdução de $O$ Desertor é o próprio Silva Alvarenga que dá posses dos domínios que entende por «reforma». Primeiro deixa claro a negação do afeto estático, fruto da ideologia da ideia inata. Afirma que, ao contrário da geração da qual ele descende, pode-se muito bem opor gêneros
} 
MUSICA THEORICA Revista da Associação Brasileira de Teoria e Análise Musical 2018, v. 3, n. 2, p. 159-188 - Journal of the Brazilian Society for Music Theory and Analysis@ TeMA 2018 - ISSN 2525-5541

commiseratio et lacryma, alternados com os elementos eufóricos da categoria furor et indignatio. Mais, considerando que o motete, enquanto gênero, é caracterizado pela polifonia ou pela homofonia rítmica, isto é, pela presença da harmonia, o responsável desse discurso foi o uníssono do exordium. Foi ele que criou uma marca ${ }^{12}$ que indexou toda a unidade musical.

Em síntese, foi na dispositio, que a estratégia do jogo dos estilos revela o discurso da redenção, como propomos em tese. E mais, observando essa disposição, acreditamos que a dispositio acaba revelando o andamento do motete vinculado a ideia do penitencial, e não da pastoral. Em outras palavras, um andamento moderato-lento que possa intensificar o funcionamento da expressividade em ombra onde emerge a pastoral siciliana.

\subsection{A elocutio}

Como nosso argumento se centra numa tropificação de uma marcha penitencial caracterizada por uma pastoral (um token), consideramos que o campo expressivo de sustentação é a ombra. Isso já expusemos acima. No entanto, há algumas escolhas bastante complexas como a tonalidade maior preponderante que nos remete novamente a explicações. E esse é um campo que ao mesmo tempo faz parte da inventio, porém tangencia a elocutio, ou seja, as escolhas de figuras de intensificação.

Primeiro há que se dizer que a elocutio não se restringe a gestualidades para destacar determinada palavra ou trecho, ela também envolve questões de

visando a clarificação de um mesmo sentimento. O Desertor, poema herói-cômico é o caso. Fazendo a conjunção (o que passo a entender como tropificação) entre os estilos trágico e cômico Silva Alvarenga busca um alargamento das possibilidades persuasivas na destruição dos limites que cada estilo impõe a priori"'(Machado Neto 2017, p. 40).

12 O conceito de markedness proposto por Robert Hatten fundamenta-se na ideia de particularização de um conceito universal através de uma ligação desse universal com algum elemento que o distinga. Vejamos o caso da terça de picardia que o próprio Hatten (1997, p. 40) usa para explicar o fenômeno. Para os ouvidos contemporâneos, a oposição da tríade tônica maior em relação à uma obra em modo menor - o que foi denominado pela tradição como terça de picardia - é uma marcação (markedness). No entanto, seu uso repetido e costumeiro a tornou uma forte convenção dentro do estilo, de modo a criar-se a expectativa de que toda música no modo menor terminasse com a terça de picardia. Daí então, quando o final de uma música no modo menor nega a convenção criada mantendo o acorde de tônica menor, todo o trecho (ou obra) resignifica, ou seja, uma nova gama de significados passa a operar na sua interpretação comunicativa. 
harmonias ou até mesmo tonalidades. Nesse caso, acreditamos que a tonalidade maior em um discurso onde uma pastoral siciliana faz parte de uma concepção discursiva em ombra (reiteramos, ambos campos tradicionalmente em modo menor) jogou um aspecto de intensificação retórica para ajudar a exposição do argumento, inclusive do sentido da tópica eclesiástica penitencial do c. 9.

Se tivéssemos uma visão mecânica do jogo das tonalidades, a preponderância da tonalidade maior enfraqueceria a tese da ombra. No entanto, além de outros elementos que são indicativos da ombra, como a textura (pieno) e

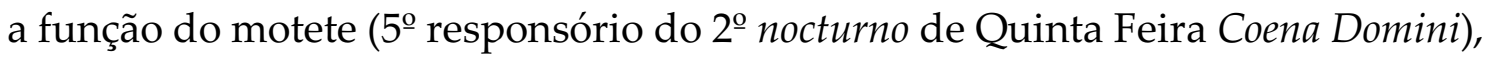
a quebra de expectativa da tonalidade é justamente parte do impacto emocional que parece ter buscado José Maurício. Isso, aliás, fica evidente quando a parte central da unidade musical toniciza para Dó maior, o que seria natural para uma pastoral siciliana e para o ambiente de ombra. Em outras palavras, o modo maior funciona como figura de modulação do ombra para um estilo eclesiástico em pieno, quebrando as expectativas de quem já estava escutando uma pastoral siciliana, apresentada em forma de monodia. Isso quer dizer, que a quebra da expectativa, assim, foi um trabalho da elocução.

Expusemos esse problema para destacar que o discurso não se estabelece somente por usos das tópicas (tanto de estilos, tipos e gestualidades) como também de figuras de retórica e suas disposições. Há um jogo de escolhas e usos de estratégias que fazem parte da perícia de compositores que tinham a retórica como fundamentos de seus saberes. Lembremos das importantes palavras de Sisman:

Um tópico, ou topos, faz parte da invenção retórica (inventio), que busca lugares-comuns (loci topici) como matéria-prima, ou parte de arranjo (dispositio), que ordena os argumentos em um todo coerente? Ou faz parte do estilo (elocutio), que escolhe a linguagem figurativa apropriada para vestir o tema, ou parte do desempenho ou entrega (pronuntiatio), em que gesto e tonalidade transmitem significado e carregam poder de persuasão? De fato, a matriz de tópicos do final do século XVIII participa de todas essas áreas (Sisman 1993, p. 69).13

\footnotetext{
${ }^{13}$ Is a topic, or topos, part of rhetorical invention (inventio), which seeks commonplaces (loci topici) as subject matter, or part of arrangement (dispositio), which orders the arguments into a coherent whole? Or is it part of style (elocutio), which chooses appropriate figurative language to clothe the subject, or part of performance or delivery (pronuntiatio), in which gesture and tone convey meaning and carry persuasive power? In fact, the array of topics of the later eighteenth century participates in all of these áreas (Sisman 1993, p. 69).
} 
MUSICA THEORICA Revista da Associação Brasileira de Teoria e Análise Musical 2018, v. 3, n. 2, p. 159-188 - Journal of the Brazilian Society for Music Theory and Analysis@ TeMA 2018 - ISSN 2525-5541

Dito isso, vejamos como outras escolhas retóricas "apoiaram" a construção de um discurso complexo por natureza: expor a condição complexa da cena da Santa Ceia, inclusive da perspectiva de muitas redenções.

A primeira questão é a da textura. Esta, assim como a harmonia, cumpre função primordial neste jogo de contrastes e sobreposições a começar com um uníssono (Exemplo 4) que se converte em uma homofonia rítmica a 6 vozes $^{14}$ (Exemplo 5) em $p p$ (pianíssimo). Junto com a harmonia, que define a tonalidade de Mi, maior, e a melodia inicial que é cantada na voz superior numa região terça acima, José Maurício escreve uma textura que intensifica a questão penitencial, o pieno. Assim, se a gravidade da marcha penitencial do exordium enfatiza a dignidade da função, saindo dessa seção, a clareza da harmonia, a leveza da dinâmica em $p p$ e a delicadeza do estilo siciliano que dela emana enfatiza a ternura num estilo eclesiástico em torno da personagem de Cristo, que como um cordeiro inocente não nega o beijo a Judas.

Entretanto, o discurso musical de Pe. José Maurício não põe a questão de maneira maniqueísta. Para realçar a ideia do contraste afetivo como baseado numa ideia otimista da redenção, sem perder o controle do ambiente de pesarsem abandonar o pieno-o compositor explora alguns elementos da ombra, como os cromatismos. Nesse momento, as figuras de retórica começam a atuar mais explicitamente.

Como podemos ver na Exemplo 5, José Maurício de modo sutil coloca uma linha cromática descendente (quase um lamento) nas partes vocais internas da malha musical. A gestualidade do marcial também se apresenta na homofonia rítmica sobre as palavras non negavit. Assim, com resquícios de lamento e a presença da trombeta marcial, a proposição da tese também se dá, intrinsecamente, na inserção de elementos de pathpoeia até mesmo numa seção de afirmação (Exemplo 5). Em outras palavras, José Maurício usa figuras retóricas para manter a atenção na tese da ambiguidade, mesmo quando a seção está no sentido afetivo oposto.

${ }^{14}$ Soprano I e II, contralto, tenor e baixo com divise. 


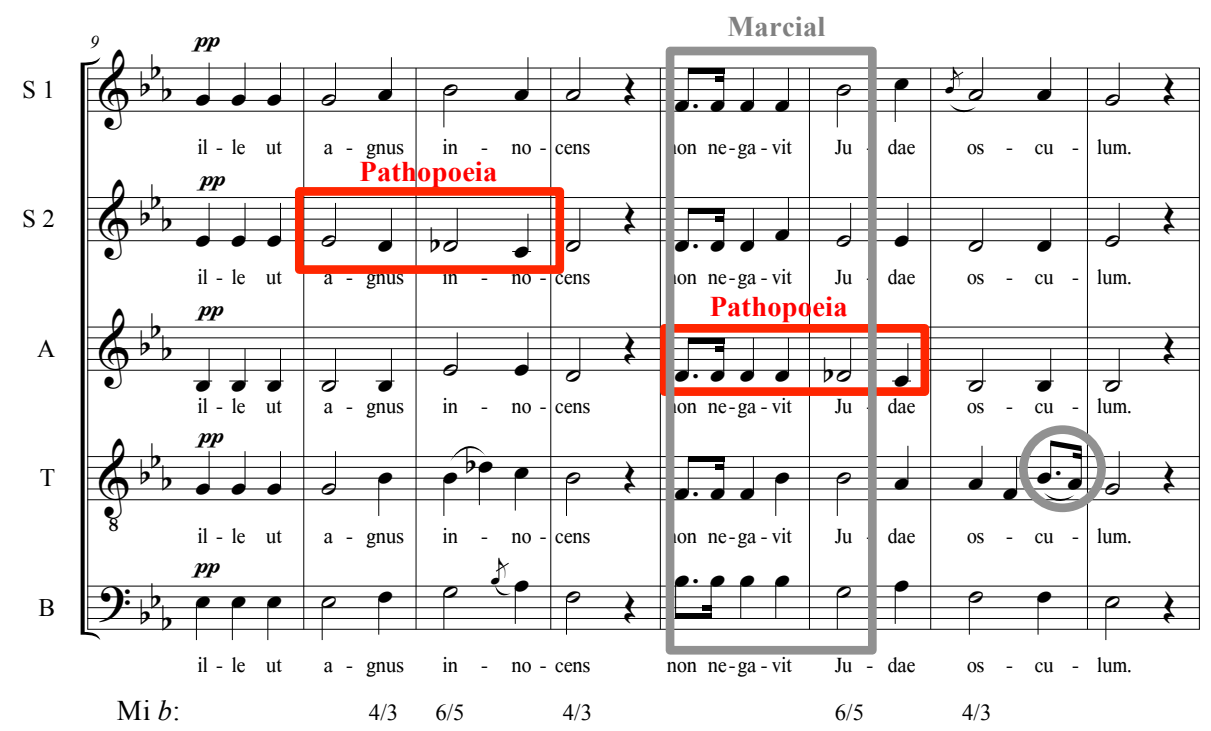

Exemplo 5: siciliano com cromatismos característicos do campo de ombra.

Ainda no espaço da elocução, José Maurício usa um recurso retórico que constitui num ponto importante do problema musical no sentido da ambiguidade. Através de uma palilogia ${ }^{15}$ - repetição do texto que normalmente traz ênfase à uma determinada ideia - o compositor escreve a música do frase Judas mercator pessimus.

Para compreender o impacto da palilogia é necessário observar a origem da ação, ou seja, o compasso 17 (Exemplo 6). No entanto, é preciso, também, ter em vista que o ponto principal dessa escrita é a repetição do texto quando a harmonia desloca-se para o modo menor (região de Dó menor), ou seja, a mudança do modo maior para a região do modo menor que desloca a música para o campo expressivo da ombra retomando o loci topici. ${ }^{16}$

${ }^{15}$ PALILOGIA: uma repetição de tema, seja em diferentes alturas em vários ou no mesmo tom na mesma voz. [...] Em seu [escrito] posterior Musica Poetica, Burmeister coloca duas limitações na repetição: ela deve ocorrer em apenas uma voz, e deve estar no mesmo tom (Bartel 1997, p. 342) [tradução dos próprios autores].

${ }_{16}$ Essa estratégia de ocultar o sentido genérico-o lugar comum-é uma estratégia bastante comum no período, e podemos encontra-la em obras como o primeiro movimento da Sinfonia oㅜ 80, quando Haydn "esconde" sob uma Tempesta um baixo de minueto que será exposto em plenitude no terceiro movimento. Há uma ideia de "jogo" de reconhecimento na qual o ouvinte é instado a criar relações de recorrências através da trama musical. A elisão, por exemplo, é uma das formas prediletas dos compositores. A outra, como vemos em José Maurício, é a suspensão da expectativa negando a natureza da tópica, como apresentar uma pastoral siciliana em modo maior, antes do modo menor. 
MUSICA THEORICA Revista da Associação Brasileira de Teoria e Análise Musical 2018, v. 3, n. 2, p. 159-188 - Journal of the Brazilian Society for Music Theory and Analysis@ TeMA 2018 - ISSN 2525-5541

Dito isso, sublinhamos, primeiro, que na camada superior da textura há uma epizeuxis ${ }^{17}$, em dinâmica de $f$ (forte), que emula a gestualidade de uma trombeta com a figura rítmica pontuada sobre a palavra "pessimus". Na camada intermediária, a harmonia opera como um extrato da cadência plagal, faz a progressão I-IV-I sobre pedal de tônica na camada inferior; isso será reiterado no modo menor, num pedal tonicizado. O pedal, por sua vez, desvela a natureza do afeto: a pastoral (inclusive com a célula pontilhada) (Exemplo 6). Mais, a figuração marcial sobre o plagal (o que dá um toque de estilo eclesiástico), apoiados pelo bordão (fragmento de pastoral), pode vir a sugerir na escrita de Pe. José Maurício uma significação em três níveis: o juízo divino (plano superior), o eclesiástico (juízo intermediário) e o lugar terreno onde se consubstanciam os fatos (plano inferior). Ademais, a mesma estrutura repetida consecutivamente no modo menor marca justamente o espaço da dúvida, o lamento e a fragilidade humana.

Visto assim, essa disposição pela palilogia nos leva inclusive a pensar que José Maurício parece questionar a afirmação: Judas seria mesmo um mercenário vil?.

Seguindo nas estratégias da elocutio, ou seja, a intensificação do discurso pelo uso dos estilos e figuras de retórica, vemos que o siciliano (sem o pedal característico da pastoral) é retomado nos compassos que seguem. A harmonia se amplia no campo do modo menor e culmina numa cadência suspensiva no modo maior. Neste trajeto, a instabilidade harmônica é intensificada por uma

\footnotetext{
${ }_{17}$ EPIZEUXIS: uma repetição imediata e enfática de uma palavra, nota, motivo ou frase (Bartel 1997, p. 263)[tradução dos próprios autores]. Aqui, Pe. José Maurício parece fazer uma espécie de pintura de palavra (word-painting), contudo, não de maneira óbvia ou inocente marcada por um certo literalismo, mas, com uma relação mais profunda entre texto e música. Supomos que há dois conceitos envolvidos: o de word-painting e o de pictorialismo. O primeiro "é o correspondente de uma palavra [ou frase] no texto em uma figura musical" [Ratner 1980, p. 25] e, o segundo, "normalmente associado à música instrumental, transmite uma ideia de uma ação ou cena" (Ibidem). No presente caso, a epizeuxis parece atuar no plano do símbolo em detrimento do ícone, afinal, a figura musical não está representando ou imitando a palavra cantada, mas, está associando a ela uma ideia, um objeto externo portador de significados relacionados ao caráter da personagem sobre qual se está cantando. É como se a música com seu pictorialismo, ao se associar à palavra trouxesse um significado externo à própria palavra. Aqui, talvez seja uma menção sobre o juízo final ou sobre o julgamento da própria personagem, um sinal de condenação.
} 
SILVA, R. L. e MACHADO NETO, D. "Judas mercator pessimus" de Pe. José Mauricio Nunes Garcia: o espaço da significação musical na expressão do motete

gradatio com pathopoeia ${ }^{18}$ - cromatismos ascendentes-no soprano II. Isso aumenta a tensão em direção à cadência suspensiva, cuja posição do acorde dominante (6/5) também denota instabilidade (Exemplo 7).

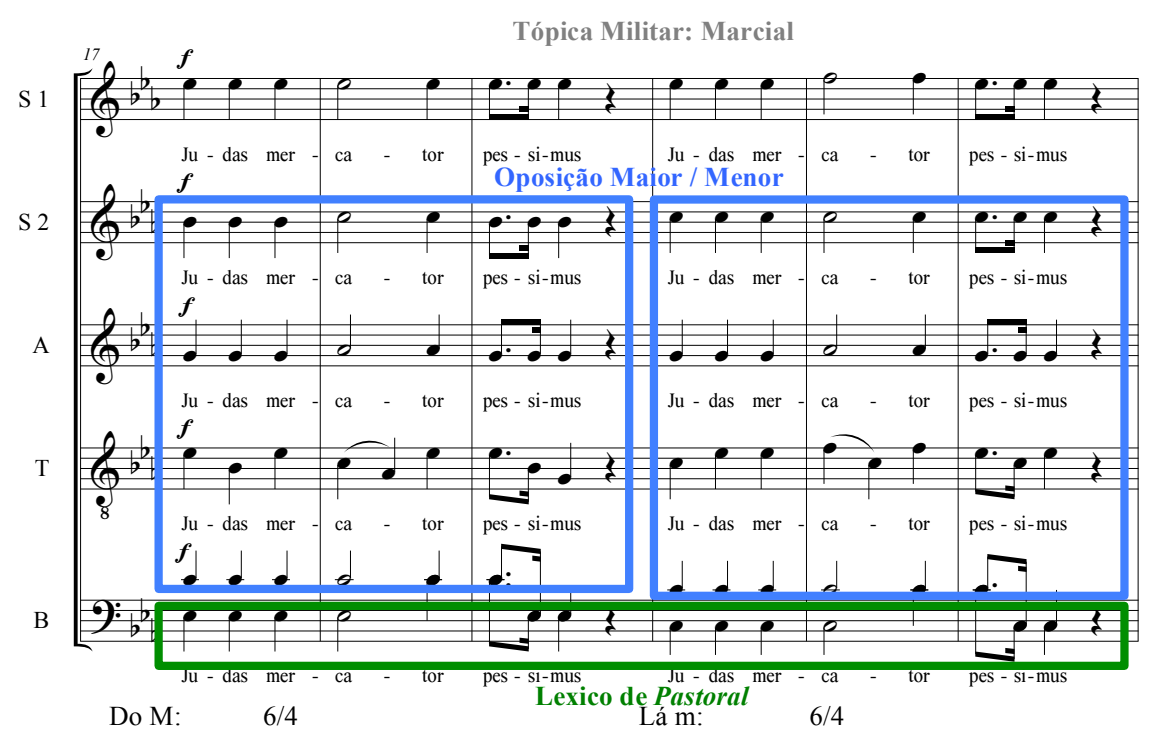

Exemplo 6: Palilogia com justaposição do modo maior vs. modo menor (17 22).

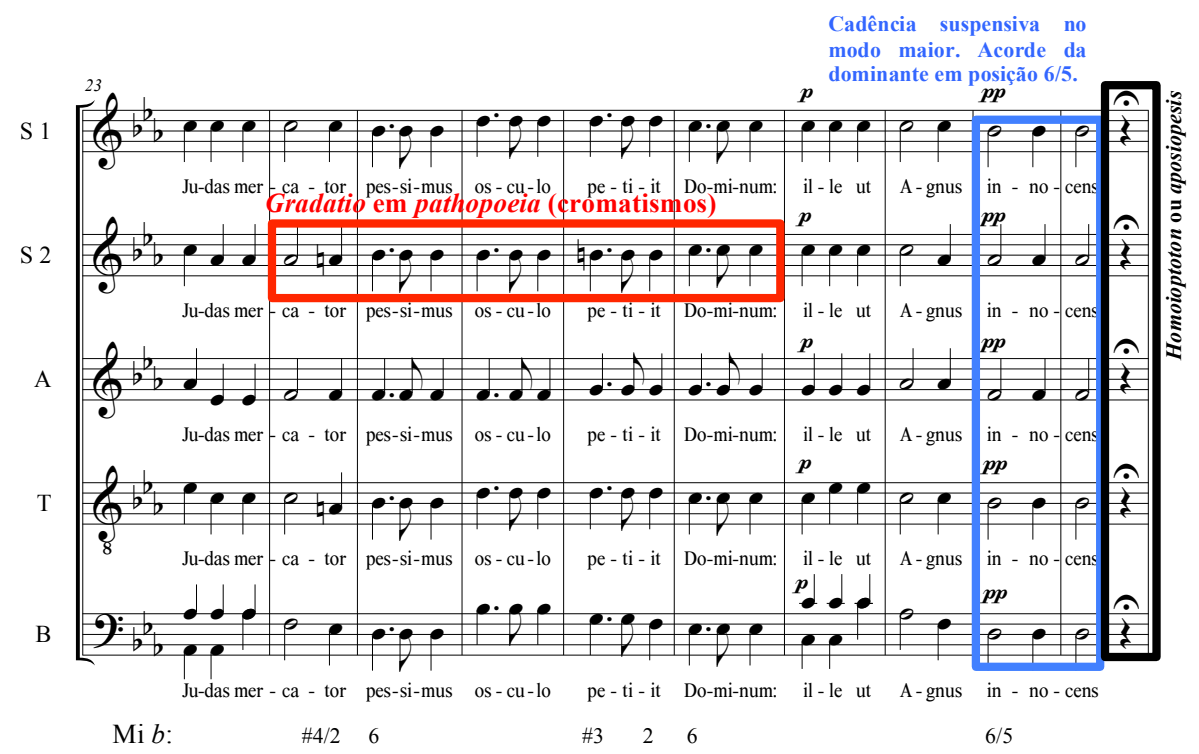

Exemplo 7: Siciliano justaposto com ombra: gradatio em pathopoeia, cadência suspensiva no modo maior e aposiopesis.

Outrossim, a presença do acorde de Dom no trecho acima analisado, dentro do conceito de marcação, desempenha notável papel. Hatten entende a

${ }^{18}$ PATHOPOEIA: uma passagem musical que procura despertar uma afeição apaixonada através do cromatismo ou de outros meios (Bartel 1997, p. 359) [tradução dos próprios autores]. 
MUSICA THEORICA Revista da Associação Brasileira de Teoria e Análise Musical 2018, v. 3, n. 2, p. 159-188 - Journal of the Brazilian Society for Music Theory and Analysis@ TeMA 2018 - ISSN 2525-5541

"mistura" de modos no âmbito da significação na música do período clássico como um elemento eloquente: "o modo menor [...] não é susceptível de ser usado de forma não-trágica em obras clássicas, e a mistura modal [...] sempre indica uma perspectiva trágica ou pungente" (Hatten 1997, p. 36). Enfim, mesmo numa pastoral siciliana, marcada pelo modo maior em progressão, há um toque de tragédia que aparece até mesmo como escrita descritiva.

A dinâmica é outro léxico importante do ombra. Geralmente os ambientes de ombra se caracterizam por fortes contrastes de intensidades. É uma determinação do estilo, porém pode ficar a disposição do elocutio.

No trecho acima (Exemplo 7), podemos ver que a dinâmica se comporta de forma escolar para uma ombra. Isso porque, apesar de predominantemente $f$, ao se aproximar da cadência suspensiva surge repentinamente um $p \mathrm{e}$, a chegada na própria cadência é feita em dinâmica $p p$ como um sussurro, uma expressão de ternura, por exemplo, na palavra "innocens" ${ }^{19}$ No mesmo sentido de realçar a ombra, ao final da gradatio (intensificada por ser cromática) a dinâmica frustra a expectativa criada pela intensificação da tensão: uma tensão harmônica, formada por um acorde 6/5, mas, de modo contrastante com dinâmica em $p p$.

Essa estratégia recebe ainda o apoio de uma aposiopesis. Figura típica do estado de ombra, a pausa (aposiopesis ou homoioptoton) ${ }^{20}$ aqui pontua um período de exposição de ideias cuja estrutura discursiva é baseada em um siliciano, no modo maior, e opostamente marcado por figurações em ombra (mistura de modo menor), para culminar na cadência suspensiva no modo maior.

Por fim, a articulação de $s f z$ (sforzando) sobre a palavra "Judae" torna ainda mais evidente o foco na personagem de Judas Iscariotes. Notemos que o $s f z$ aqui atua de forma bastante pictórica, visto que o efeito sonoro desta articulação consiste em atacar o som com intensidade $f$ e imediatamente reduzir o mesmo à dinâmica de $p$, em outras palavras, contraste sonoro. Em suma, a única palavra a ser tratada com esta articulação (sfz), em uma cadência suspensiva (com

\footnotetext{
${ }^{19}$ Esta dinâmica fora já usada anteriormente sobre o texto "ille ut agnus innocens non negavit osculum" (9 - 16) sendo aqui, a palavra "innocens" a repetição de um fragmento.

${ }^{20}$ PAUSA: uma pausa ou descanso em uma composição (Bartel 1997, p. 362). Muitas são as figuras retóricas caracterizadas por pausa: abruptio, supiratio, ellipsis, tmesis, aposiopesis, homoioptoton, homoioteleuton, pausa, mas, segundo Bartel, designa "uma pausa geral em todas as vozes (aposiopesis), ou a interrupção da composição (homoioptoton)" (Bartel 1997, p. 295) [tradução dos próprios autores].
} 
dinâmica contrastante em $p p$ ), no ponto culminante da exposição do problema musical a sintetizar emblematicamente o papel da personagem na trama: contraste, antagonismo, ambiguidade, enfim, instabilidade.

Em síntese, dois tipos de gestualidade musical foram apresentadas: (a) um gesto de caráter mais disfórico de um siciliano com marcações em ombra (em forma de marcha penitencial, inclusive); e (b) um gesto de caráter afirmativo, a figura da trombeta com fragmentos de harmonia plagal. Esses gestos ocorrem sucessivamente $\left(\begin{array}{llll}a & b & a^{1} & b^{1}\end{array}\right)$ entrelaçados pela ambiguidade modo maior/modo menor.

Em conclusão, essas estratégias de figuração conseguem, assim, cumprir com a ideia do discurso: apresentar um personagem central da Paixão de Cristo sem que a perspectiva da condenação seja a única referencia. Inclusive porque a morte (no ambiente de ombra marcado pela marcha), nesse caso, é associada com a redenção que atinge o próprio traidor de Cristo, ou mesmo a ideia de que a morte de Cristo é o caminho para a redenção de toda a humanidade.

\section{Conclusão}

Como parte de uma pesquisa ainda em andamento, até aqui nos ocupamos em expor as proposições contidas no discurso musical na primeira parte (moderato) do motete Judas mercator pessimus de Pe. José Maurício Nunes Garcia.

Durante este percurso, demos início à uma investigação mais ampla no âmbito da significação no sentido de compreendermos o papel exercido pela música, dado que, no gênero do motete o texto assume o protagonismo enquanto elemento discursivo. Na obra objeto de nossa análise constatamos uma relativa oposição da música em relação ao texto: a dubiedade dos parâmetros musicais reveladores da ambiguidade dos afetos e do antagonismo entre música e texto.

Contudo, a música constitui um segundo texto que comenta através de seus próprios elementos significativos aspectos que estão além dos limites objetivos da palavra. A música acrescenta ao texto ideias não explícitas, mas, que revelam uma determinada compreensão deste mesmo texto sob a ótica de um exímio orador sacro. Pe. José Mauricio em altíssimo nível simula no discurso musical um diálogo didático entre o indivíduo e o senso coletivo histórico a respeito do tema proposto pelo texto-o caráter da personagem central na trama, Judas Iscariotes. O discurso musical consubstancia, assim, um estado de dúvida 
e incerteza que gradativamente ganha densidade e profundidade na lógica dos argumentos entrelaçados (ainda que embebida de subjetividades) e, encontra na dialética de seu próprio conflito a esperança de um caminho para a salvação da personagem central, ou compreender a essência do sacrifício pascal, tendo como plano de fundo o projeto ideológico o qual compartilha com a sua audiência.

Destarte, este processo de análise e busca pelo significado musical não visa estabelecer um significado rígido a esta ou qualquer outra obra, mas, buscar evidências de uma comunicação pensada e realizada através de ferramentas expressivas sonoras que se apropria dos códigos de sua época e se corresponde com uma escuta atenta e que em algum nível-às vezes mais, outras vezes menos consciente-absorve e compreende a mensagem transmitida ao corpo social local e temporal. Cabe a nós resgatar, por meio de um estudo interdisciplinar, tal escuta significativa, seja com o intuito de materializar a música na performance, seja com o intuito de compreender a complexidade presente nas muitas formas do pensamento humano.

\section{Referências}

1. Bartel, Dietrich. 1997. Musica Poetica: Musical-Rhetorical Figures in German Baroque Music. Lincoln e London: University of Nebraska Press.

2. Biblia de Jerusalém, Nova edição revisada. $7^{a}$ impressão (1995). São Paulo: Editora Paulus.

3. Cooper, Grosvenor; Meyer, Leonard B. 1960. The rhythmic structure of music. Chicago: The University of Chicago Press.

4. Grout, Donald J. e Palisca, Claude V. 1997. História da Música Ocidental. Tradução: Ana Luisa Faria. $2^{a}$ edição. Lisboa: Gradiva.

5. Cipolini, Pedro Carlos. 2010. A devoção mariana no Brasil. Porto Alegre: Revista Teocomunicações, v. 40, n. 1, p. 36-43.

6. Ferguson, Sinclair B; Wright, David F. 2009. Novo dicionário de teologia. São Paulo: Editora Hagnos.

7. Hatten, Robert. 1994. Musical Meaning in Beethoven: markedness, correlation and interpretation advances in semiotics. Bloomington \& Indianapolis: Indiana University Press.

8. Jung, Hermann. 1980. Die Pastorale: Studien zur Geschichte eines musikalischen Topos. Bern: Francke. 
9. Levy, Janet M. 1982. Texture as a Sign in Classic and Early Romantic Music. Journal of the American Musicological Society, v. 35, n. 3, p. 482-497.

10. Machado Neto, Diósnio. 2015. A manifestação do iluminismo católigo em José Mauricio Nunes Garcia: a missa de Nossa Senhora da Conceição (1810). Congresso Caravelas, Lisboa. Música, Cultura e Identidade no bicentenário da elevação do Brasil a Reino Unido, Atas do congresso internacional. São Paulo.

11. Mattos, Cleofe Person. 1970. Catálogo temárico: José Mauricio Nunes Garcia. Rio de Janeiro: Gráfica Olímpica Editora Ltda.

12. ___ 1976. Obras a cappella: José Mauricio Nunes Garcia. Rio de Janeiro: Associação de Canto coral do Rio de Janeiro.

13. __ 1996. José Mauricio Nunes Garcia: bibliografia. Rio de Janeiro: Fundação Biblioteca Nacional, Dep. Nacional do Livro.

14. Mcclelland, Clive. 2012. Ombra: Supernatural Music in the Eighteenth Century. Lanham, UK: Lexington Books.

15. Mirka, Danuta. 2014. The Oxford handbook of topic theory. New York: Oxford University Press.

16. Monelle, Raymond. 2006. The musical topic: hunt, military and pastoral. Bloomington: Indiana University Press.

17. Montfort, Luis Grion de. 2002. Tratado da verdadeira devoção à Santíssima Virgem Maria. Anápolis: Imprimatur.

18. Ratner, Leonard G. 1980. Classic Music: expression, form and style. New York: Shirmer Books.

19. The New Grove dictionary of music and musicians. 1995. Editado por Stanley Sadie. New York: MacMillan Press Ltda. 